Strategic Positioning for Professional Service Firm Internationalisation:

The Case of Architectural Practice

Graham M Winch

Manchester Business School

Manchester M15 6PB

01614346956

graham.winch@mbs.ac.uk 


\title{
Strategic Business and Network Positioning for Internationalisation
}

\begin{abstract}
Despite growing research interest in the internationalisation of professional service firms, little research has investigated the implications of home market business positioning for network positioning in professional service firm internationalisation strategy. This paper develops theory in the service industries by investigating strategic positioning in professional service firm internationalisation through analysis of a case survey of 53 architectural practices. The results of this empirical analysis allow us to develop a configuration analysis of strategic positioning for professional service firm internationalisation as the principal theoretical contribution of this paper.
\end{abstract}

\section{Key Words}

Professional service firm; internationalisation; business positioning; network positioning; architectural practice;

\section{Introduction}

Over the last few years, there has been growing interest in the management of professional service firms and there is now a considerable body of literature on the organisation of these distinctive types of firm (Brock 2006; Malhotra \& Morris 2009; von Nordenflycht 2010). More recently, attention has turned to the internationalisation of professional service firms (Apfelthaler \& Vaiman 2012; Brock 2012), in the context of a growing interest in service firm internationalisation more generally (Pla-Barber \& Ghauri 2012), as they play an increasing role in international trade (Abdelzaher 2012). However, little of this research on professional service firm internationalisation has investigated the implications of home 
market strategic positioning for internationalisation strategy. This paper contributes to theory by developing a configuration analysis of the relationship between home market strategic positioning and network positioning for internationalisation strategy.

The paper starts by briefly reviewing the literature on the internationalisation of professional service firms, and on business positioning and network positioning for professional service firms. The argument then moves on to identify architectural practice as an appropriate domain for the empirical exploration of professional service firm internationalisation. The data from a case survey of 53 British and French architectural practices is then presented as a single data set, analysed using QSR N6 as a data management tool. The focus of our enquiry will be on the relationship between the ways firms position themselves in the home market for architectural services defined as business positioning and they ways in which they enter into alliance networks as they internationalise defined as network positioning. We develop the theoretical implications of our findings through a configuration analysis of strategic positioning for the internationalisation of professional services firms. Suggestions for further work and conclusions follow.

\section{The Internationalisation of Professional Service Firms}

The challenges of globalisation are generating considerable organisational pressures on professional service firms as they grapple with the issues inherent in combining consistent service to global clients with responsiveness to the specificities of local markets. Early studies focused on identifying the phenomenon in general and its geographical distribution (Aharoni 1993) while noting the importance of regional centres such as London in that phenomenon such as Beaverstock, Taylor and Smith (1999) on law and Rimmer (1988) on engineering design. Other studies looked at organisational issues such as Cooper, Rose, Greenwood and Hinings (2000) and Daniels, Thrift and Leyshon (1989) on accountancy; 
Spar (1997) on law and Winch (2008) on architecture. More recently, attention has turned to the internal resources of the firm in internationalisation (Boussebaa 2009; Hitt, Bierman, Uhlenbruck \& Shimizu 2006; Scott-Kennel \& von Batenburg 2012) and the processes of internationalisation (Krull, Smith \& Ge 2012). Some of these studies noted in passing that professional service firms tend initially to follow their clients abroad as the mode of market entry and the importance of firm size in internationalisation (e.g. Aharoni 1999; Rose \& Hinings 1999; Spar 1997).

Research has started to look at the relationships between the market-related business positioning of firms in their home countries and internationalisation processes. Some looked at market structure - Nachum (1997) looked at home country rivalry in advertising, while Scheuer (2003) looked at the effect of home country demand on internationalisation in engineering design. Others took a more institutional perspective such as Cooper et al (2000) on accountancy, Boussebaa, Morgan and Sturdy (2009) on management consultancy, and Morgan and Quack (2005) on law. However, none of this research conceptualises the professional service firm as a strategic actor and then explores the relationship between the chosen strategic positioning in the home market and internationalisations processes. Perhaps only Segal-Horn and Dean (2011) on law theorise the internationalising professional service firm as a strategic actor; however, they focus on industry drivers rather than firm positioning in relation to those drivers. It is this connection between home market strategic business positioning and internationalisation processes that this paper seeks to address and thereby contribute to theory.

\section{Strategic Positioning of Professional Service Firms}

Research on strategic positioning is epitomised by Porter (1980) and theorises the relationship between the positioning of a firm in its market and its performance. This 
research, therefore, focuses on the "firm's relative position within its industry" (Porter 1985:11) in an "external analysis” (Barney 1991: figure 1) of the firm. In contrast, the resource-based view focuses on the "internal analysis” (Barney 1991: figure 1) of the firm. The resource-based and positioning approaches to strategy are complements rather than substitutes (Barney 2001; Wernerfelt, 1984) and both are required for a full understanding of firm internationalisation (Peng, Sun, Pinkham \& Chen 2009). In this paper we address both positioning and resources as we explore the relationship between home market positioning and its relationship to network positioning as a way of accessing the resources available in the international market required for deployment in those markets. We therefore focus on the firm as a strategic actor as the unit of analysis, and do not address the issues of market structure associated with the broader field of industrial organization with its focus on the industry as the unit of analysis.

Subsequent research has suggested that, at least for professional service firms, the concept of firm positioning needs to be elaborated to distinguish business positioning which identifies the firm's relationship with its industrial competitors and network positioning (Koka \& Prescott 2008) which identifies the firm's relationship with its alliance collaborators. The application of the business positioning perspective to professional service firms was pioneered by Maister (1982) for law and developed empirically for architectural practice by aligning it more closely with Porter’s (1980) framework (Winch \& Schneider 1993). While Maister's work conflated internal and external dimensions in his construct, the dimensions in the Winch and Schneider construct, as discussed below, are both external. Jones, Hesterly, Fladmoe-Lindquist and Borgatti (1998) have elaborated how professional service firms articulate their relationship to the alliance constellations within which they deliver their service offers, thereby applying the network positioning concept to professional service firms. Research in the steel industry (Koka \& Prescott 2008) suggests that there is a link between business positioning and network positioning and argues that firms need to design 
their alliance networks in order to be able to respond effectively to change. This strongly suggests that we can expect to find a connection between business positioning and network positioning amongst our case professional service firms. We therefore enter the field with two distinctive constructs - the business positioning and network positioning constructs and the expectation that there is a link between the two. We now elaborate these constructs in more detail.

Focusing on architectural practice, Winch and Schneider (1993) empirically identified four generic strategies; conceptually, these generic strategies are based on Porter's (1980) work but are adapted to be more relevant to professional service firms by identifying the distinctive features of the market for architectural services drawing on two dimensions of market demand - project complexity and the client's quality preference - as shown in figure 1. Strong delivery focuses on relatively simple building types and meeting client needs cheaply and effectively. Strong experience focuses on relatively complex building types, solving difficult architectural problems to meet clients’ operational requirements. Strong ambition focuses on winning a first major commission, and the principals may be making a living through teaching in architecture schools or entering an architectural competition. Finally strong ideas is about the opportunity is to create a landmark building because the client requires that the building be noticed - this is the world of the "star system" (Larson 1993). Here the crucial factor in winning a commission is a reputation for original and exciting solutions. Such work is usually obtained by winning an architectural competition or by invitation from architecturally literate clients. These four "generic strategies” (Porter 1980) adapted to the specific market context of architectural practice provide the parameters of our business positioning construct. 
Jones et al (1998) build on network theory to argue that professional service firms such as architectural practices typically work in "constellations” of multilateral relationships, where constellations are defined as a "group of firms that interact directly and reciprocally to coordinate their efforts for a complex service or product during a finite period of time” (1998: 398). They articulate two distinctive strategies for working in constellations:

- Promiscuity, where the firm takes an individualistic approach to collaboration using the constellation as a vehicle to hone its own specialist skills through multiple challenging assignments which provide diverse learning opportunities.

- Polygamy, in distinction from the monogamy of the bilateral strategic alliance, where firms pursue a collective advantage by identifying with a network of stable relationships deploying synergistic skills which mutually reinforce skills.

These two "constellations" provide the parameters of our network positioning construct. The interaction of these two constructs in the context of internationalisation generates our research question: how does home market positioning for professional service firms affect the choice of network positioning in alliance constellations when moving into international markets?

\section{Data and Method}

In order to explore this question, we have chosen to investigate the strategies used by firms when they are exporting architectural services to clients based in countries other than the home base of the practice. We suggest that this field of enquiry represents a good test for professional service firm strategy research for a number of reasons. First, investigating architectural practice allows us to move beyond the "usual suspects” of law and accountancy in the study of classic professional service firms (von Nordenflycht 2010) to investigate a sector where competition relies on creativity rather than probity in meetings clients' needs 
(Winch \& Schneider 1993). Second, architectural practice has been a rapidly growing area of professional service firm internationalisation over the last 20 years (McNeill 2009); finally, we are controlling for possible inter-sectoral and inter-professional differences by focusing on one professional sector.

Our approach in this research is positivist in that we use a case study approach to enable the development of testable theory (Eisenhardt 1989; Eisenhardt \& Graebner 2007). Case study firms were sampled theoretically to find firms that are facing new challenges by working abroad. It should be noted that these firms form only a small proportion of the total population of firms in the architectural services sector in the two countries. The selected firms form our units of analysis and we stayed within the replication logic (Yin 2009) of case study research by not inferring from these results to a larger population. Case study researchers are typically recommended to use multiple cases for theory-building but also to restrict their number of cases to under 10 (Eisenhardt 1989; Yin 2009) so as to keep the data set manageable. However, we were able to take advantage of the recent availability of qualitative data management tools in the context of a focused research question to move more towards a case survey methodology (Larsson 1993) in which a larger number of original case studies is developed and coded allowing both theory testing and theory building.

The aim was to interview 30 practices in each of France and England about their experience of working in the other country. We wanted to include firms from more than one country so as to avoid an anglo-centric bias in the data. As with most UK professional associations, England and Wales, Scotland, and Ireland are organised independently and the Royal Institute of British Architects (RIBA) only covers the first two countries of the Union; in this research, "England" is therefore shorthand for England and Wales, not the UK. The English ones were sampled from the RIBA Compendium of International Practices, from which it 
was possible to identify practices which had worked internationally. No such document exists in France, and we were obliged to use snowball methods to identify practices for inclusion in the survey by working with the professional association (Ordre des Architectes), officials of the Ministère d'Equipement, and professors at various architecture schools. It proved difficult to find 30 French practices with international experience, and the data set therefore includes only 29 French cases even though the criteria for sampling were extended to include those companies that had also worked in Germany.

Interviews were conducted with an appropriate partner or other principal of the practice as informant to a structured aide memoire in the preferred language of the informant. A copy of this aide memoire is attached at appendix one. This ensured that the basic data were collected, while allowing for particularly interesting aspects of the responses to be explored further. Each interview was combined with practice documentation and written up as a case study which was returned to the practice for verification. The verbatim quotations from our informants presented in table 1 are all taken from these case study reports. All 59 case studies were then meta-analysed by a different member of the research team from the one who prepared all the case studies using QSR N6 as a data management tool. This analysis produced the codings upon which the following quantitative analysis is based. This approach meant that the case studies were written up as narrative reports to a common structure for subsequent analysis rather than analysis and narration being conflated. In common with many qualitative data management tools, QSR N6 allows the researcher to structure the data codes into "trees" of codes and sub-codes (Davidson \& di Gregorio 2011). The codings from the QSR node tree that we generated were exported manually to SPSS as nominal variables complemented by ratio variables such as firm age and size to produce the quantitative analysis using non-parametric tests as appropriate. Table 1 provides examples of the types of text units and how they were coded. 
A preliminary analysis of our cases showed that not all could be classified as professional service firms. Two of the French strong experience practices were the technical services arms of Société Nationale des Chemins de Fer (French railways) and Aéroports de Paris (Paris airports) and thus better classified as state agencies. These had been established to provide in-house the architectural services requirements of the two state-owned organisations, and were now successfully exporting the expertise they had thereby acquired. These two were eliminated from the analysis. We also found that all but four of the professional service firms in the case survey were coded to the strong ideas or strong experience categories of the business positioning construct. This is hardly surprising, because the fee levels available in low complexity projects are unlikely to cover the additional costs of exporting architectural services such as travel, translation, and a risk premium for a relatively unfamiliar regulatory environment. These four firms - two strong ambition and two strong delivery - were also eliminated from the main analysis in the interests of parsimony. We therefore took forward a total of 53 cases for further analysis using the two binary constructs defined above.

\section{Business and Network Positioning in International Architectural Practice}

The literature on the strategic management of architectural practice discussed above identified an existing construct which we believed that we could apply in our research. The business positioning construct (Winch \& Schneider 1993) was shown to the informant and explained - see figure 1. Most informants were able to identify where their practice sat within the construct themselves, and we were able to allocate all cases to one of the strategic categories, and code the results accordingly. In the small number of cases where the 
informant did not explicitly choose a category, we used a reading of the case as a whole to make the allocation. On this basis 24 (45\%) could be coded as espousing strong ideas strategies, and 29 (55\%) as espousing strong experience strategies for positioning in their home markets. These results, we believe, show that the business positioning construct developed by Winch and Schneider (1993) is robust. An example of these codes is offered in table 1.

Once the work in the foreign country has been won, the practice must organise itself to do this work (Winch 2008). As argued above, this poses particular challenges due to the nature of the service offered which is both bespoke and highly regulated. Some sort of local expertise is required - the issues revolve around how access to this resource is to be provided. The informants were asked how they solved this problem of access to local expertise resources. From the analysis of the data, two types of response were identified:

- Come to a temporary arrangement with a local architectural practice or open a temporary local office. We argue that these practices deployed what Jones et al (1998) call a promiscuous collaboration strategy, accounting for 42 (79\% of) cases.

- Enter into some kind of permanent arrangement with other practices in target markets accounting for 11 (21\% of) cases. We argue that these practices deployed what Jones et al (1998) call a polygamous collaboration strategy.

These results, we believe, show that the construct developed by Jones et al (1998) of polygamous and promiscuous positioning with service delivery constellations is robust. An example of these codes is offered in table 1.

Having explored the constructs qualitatively and coded each of our cases to either strong ideas or strong experience business positioning in the home market and polygamous or promiscuous network positioning in gaining access to resources in the international market, 
we can now, following Koka and Prescott (2008), investigate whether the two are related. We first explored the relationship using the simple test of association presented in table 2 (null hypothesis is that there is no association). This suggests that there is, indeed, a relationship with strong ideas firms clearly favouring promiscuity, and strong experience firms showing a greater tendency to favour polygamy. However, it is also clear that promiscuity is a default network strategy for many firms on many of their projects whatever business positioning strategy they have. Thus the promiscuity would appear to be what any practice does if it is not in a position to deploy its favoured network strategy in gaining access to local resources of expertise. We tested to see whether the home market resources available to the firm made a difference to the selection of network strategy, taking number of staff (partners and employees) as a proxy for home market resources, and found that while the mean size of firms favouring a promiscuous strategy was a lot smaller than for the polygamous strategy, the high variance within each category meant that an ANOVA test did not yield significant results.

INSERT TABLE 2 ABOUT HERE

\section{Discussion: Configurations of International Practice in Professional Services Firms}

We used a case survey of 53 British and French architectural practices to explore the relationships between strategies for home market business positioning and strategies for network positioning in gaining access to resources in international markets for internationally operating professional service firms. We found that strong experience practices favour polygamous network strategies, while strong ideas practices prefer to meet the need for local expertise promiscuously (significant at the $1 \%$ level). We applied the two constructs which operationalise the perspectives on professional service firm strategy developed by Winch and 
Schneider (1993) and Jones et al (1998) to a relatively large set of cases and found them to be robust. We have, thereby, through our empirical analysis

- Replicated the business positioning construct over a much larger sample and found it to be robust for home market positioning;

- Operationalised the network positioning construct and found it to be robust for accessing resources in international markets;

- Demonstrated that network positioning and business positioning are associated for professional service firms when they internationalise.

We have also suggested that the association between these two positioning constructs is a function of the different markets that the firms espousing them address. This formulation suggests a strategic fit approach in which we identify configurations of practice (Miller 1996; Siggelkow 2011) which are both internally coherent and externally fit the market environment. We develop this configuration analysis by drawing on the analysis presented here and our 53 case studies which underpin that analysis.

We suggest that we can inductively identify two distinctive configurations of international practice in the supply of architectural services. In labelling these configurations we draw on the distinction made by our informant from Architectures Jean Nouvel between practices that are creators of architecture, and those that are constructors of buildings. Blau (1984) argues that the Daedelian risk between architecture as art and architecture as business is central to the strategy of practice, and the Nouvel categories articulate distinctive configurations of architectural practice as possible resolutions of this pervasive dilemma (Larson 1993). These two configurations are compared and contrasted in table 3.

The creators of architecture configuration is characterised by an internationalisation strategy which focuses on winning highly competitive architectural competition as the means of 
entering a foreign market. For instance, the entry of Renzo Piano into the French market was in partnership with Richard Rogers for the Centre Pompidou in Paris. It is relatively difficult for strong ideas practices to be proactive in obtaining work. Architectural competition entry is, by definition, a reactive process, as it depends on the decision of a client to mount a competition. There is also very little repeat work for strong ideas practices. While HSBC did commission Foster and Partners twice to design its prestige headquarters buildings in both Hong Kong and London, most clients for strong ideas practices typically build only one prestige building either as a corporate headquarters, or as a culturally symbolic building. As a result of this inability to structure the market, strong ideas practices need to be very flexible in reacting to market opportunities, either in the form of invitations to enter architectural competitions, or to enquiries from prospective clients. Because of this they tend to eschew polygamy in their international practice constellations, preferring some kind of temporary arrangement - either promiscuously entering into a temporary association with a small local architectural practice or setting up a temporary office staffed with local hires.

The constructors of buildings configuration is characterised by an internationalisation strategy that focuses on following corporate clients as they internationalise, bringing with them their expertise in specific building types (Winch, Grèzes \& Carr 2002). Such practices also have the opportunity to target potential foreign clients who can use their specific expertise. They can therefore be more selective in the foreign markets that they enter, and have a lower requirement for flexibility in their constellations. They therefore tend to be polygamous, setting up either managed networks of joint ventures or subsidiaries with themselves at the centre such as BDP and John R Harris, or opting for more collegial networks such as the Architecturo European Economic Interest Group (EEIG) or the Eurarc EEIG studied by Prost (1997). 
The configuration analysis presented here is based on our data on the architectural services sector but there is evidence from other professional service firm sectors that a configuration approach might yield additional insights. For instance, Segal-Horn and Dean (2011) focus on global integration as an internationalisation strategy for law firms, yet mention in passing that a viable "best friends" approach also exists. However, they do not investigate why some successful firms take the former approach and others the latter. This argument here also challenges the rather linear analysis of Brock (2006) which identifies only Global Professional Networks as viable globally. While "constructors of buildings” are closer to the Global Professional Networks archetype and our "creators of architecture” closer to the "star" archetype in his analysis, the former is not any more inherently global than the latter; indeed on the evidence of our cases the creators of architecture are more nimble internationally and can more easily encompass a wider geographic spread.

As with all research, the work presented here has limitations. The principal one is that the case firms are all architectural practices, and that the constructs are adapted to their market context. This has the important advantage of clearly locating the case firms in a specific industrial context, but it means that care needs to be taken when generalising to other professional service industries and on to the broader service sector. However, the theoretical principles behind the constructs have much broader relevance, and hence the findings here have a much broader implications for the understanding of internationalisation in the service industries. Our own unpublished research, for instance, suggests that for professional service firms providing technical services such as engineering design, the quality preference dimension can be replaced by an innovation focus dimension while the project complexity dimension remains relevant. 
A second limitation is that we have restricted the analysis to firms based in England and France; however we have no reason to believe that firms based in other countries will have systematically different experiences when internationalising. A third limitation is that the research is focused on the "external" (Barney 1991) positioning of the firm with respect to both competitors and alliance partners, and the analysis of resource positioning is limited to the acquisition of the resources required for foreign market entry from alliance partners. A more fully developed configuration analysis would also examine "internal fit" (Helfat et al 2007) and its relationship to the external fit (Porter \& Siggelkow 2008) of the firm to its market environment.

\section{Conclusions and Further Work}

Through our literature review we identified the gap in theory regarding the relationship between network positioning and business positioning and sought to empirically test this relationship. By analysing a case survey of 53 architectural practices, we have contributed to theory by showing that empirically meaningful home market business positioning strategies are strongly correlated to empirically meaningful network positioning strategies for professional service firms as they internationalise. This finding then provides the basis for a configuration analysis of strategic positioning for professional service firm internationalisation as the principal contribution to theory of this paper. Our argument has significant implications for theory development and suggests some fruitful lines of enquiry for further work.

One important line of enquiry would be to extend investigation of the relationships between business positioning and network positioning. The literature on network forms of organisation typically sets them up in opposition to firms (Brass, Galaskiewicz, Greve \& Tsai 2004), but many networks have firms as their nodes and so we need to understand more deeply how network and business positioning strategies interact. As Granovetter argues 
(1982), understanding the behaviour of nodes is a crucial part of understanding the behaviour of networks. This approach would also extend configuration analysis which tends to conceptualise externalities to the firm as the market environment in general rather than other firms in particular (Porter \& Siggelkow 2007).

A second line of enquiry would be to look more deeply inside the professional service firm to investigate the dynamic capabilities (Helfat et al 2007) that enable the firm to seize international market opportunities when most of their peers remain within their national and regional markets. This would require moving beyond the size proxy for home market resources used in this analysis. The professional service firm relies inherently on human resources for its capabilities (von Nordenflycht 2010; Winch \& Schneider 1993) and so we can expect these to be central to internationalisation (Hitt et al 2006). It would then be fruitful to integrate the analysis of dynamic capabilities with a configuration analysis as suggested by Siggelkow (2011) to provide a more holistic analysis of professional service firms.

A further line of enquiry stimulated by this research could include how constellations of international professional service firms evolve. Individual professional service firms can be seen to evolve over time from strong ambition to strong ideas to strong experience business positioning (Winch \& Schneider 1993) and can also be seen to evolve as they internationalise (Krull et al 2012). Can complementary evolutionary patterns be seen in the evolution of alliance constellations with firms moving from promiscuous to polygamous networks strategies as they grow internationally in geographic scope? The work of Koza and Lewin (1999) suggests that loosely integrated international professional service firm constellations such as Nexia are inherently unstable, while the fate of the tightly integrated (Cooper et al 2000) Andersen Worldwide where a failure in one regional unit brought down the entire international network suggests that this is not a solution either. 
In conclusion, we can suggest that the case survey method (Larsson 1993) deployed here is worthy of consideration for use more widely. In particular, case studies are an important method for configuration analyses because of the difficulties inherent in survey methodologies of capturing the full range of interactions between the various dimensions of the configuration in their particular context and the richer operationalisation of constructs that they allow (Siggelkow 2011). The use of multiple cases of relatively small units of analysis with focused research questions can yield insights which might not be available to researchers deploying more intensive case study or naturalistic methods on the one hand, and survey methods on the other and are therefore a valuable complement to such methods. 


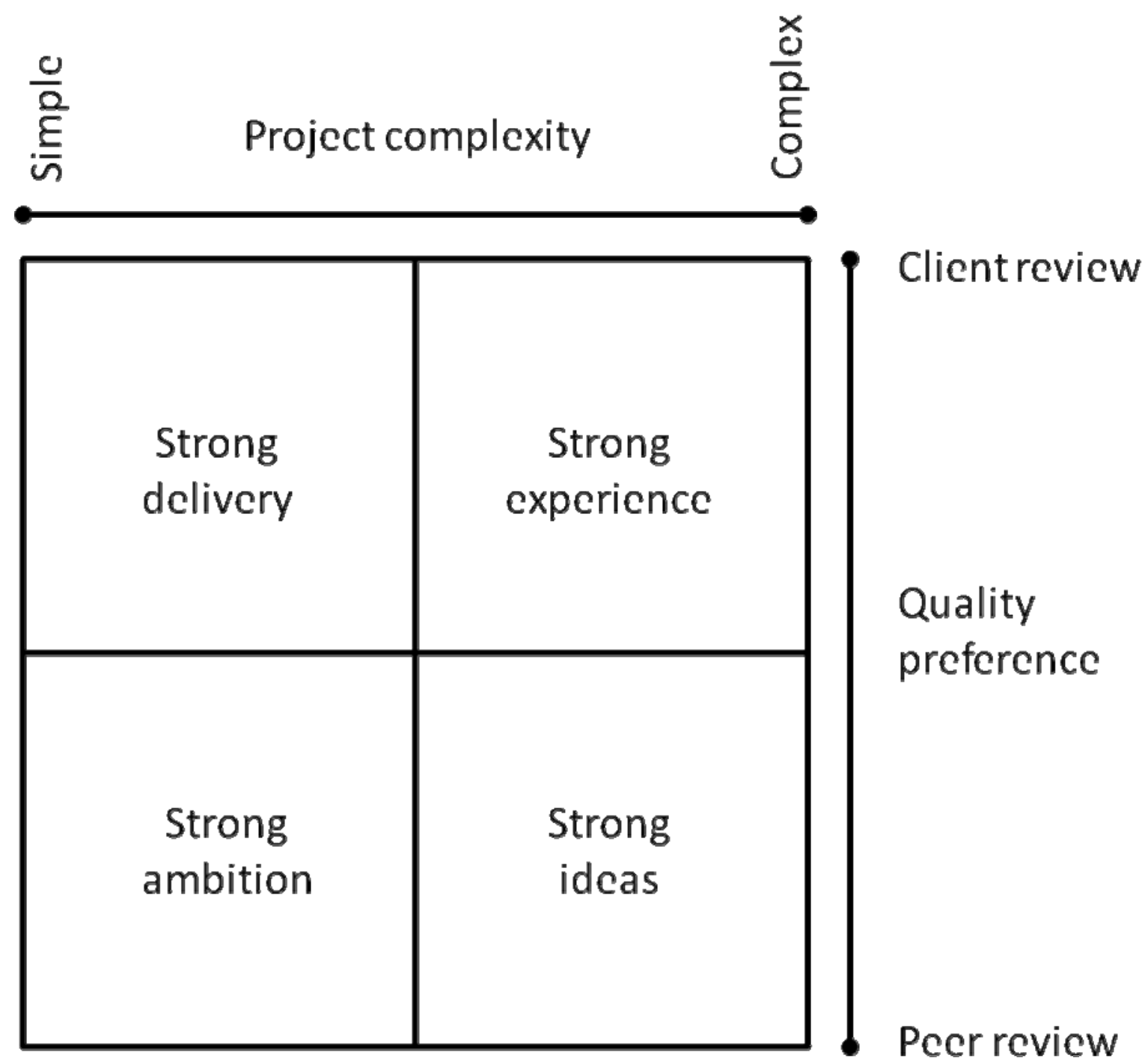

Figure 1 
Table 1 Samples of Coded Text Units.

Sample coding of strong experience business positioning

The positioning is very clear for us. We are there (strong experience) because we are confident with complex and very complex projects and recognition by my peers does not interest me. On the contrary, it is recognition by my clients which interests me. Therefore the practice does not enter many architectural competitions. We have a particular position because we are specialised in the sectors where our clients are active. Our specialisation is not to be architects or engineers, but to be specialised in the pharmaceuticals, hospital, or food industries [translated by the author].

Sample coding of strong ideas business positioning

The practice has built a very wide range of projects from low cost industrial units to prestige headquarters buildings; from highly technical laboratories to sensitive landscape proposals; from cultural centres to speculative office developments and from airport planning to restoration of historic monuments. ....Throughout the history of the practice the theme of creating public space and enlivening the city has played a vital role in shaping designs.... The practice's reputation for thorough analysis and innovation problem solving has been gained through often exhaustive consideration of each project from first principles.

Sample coding of promiscuous network positioning

We never change the way we work from project to project or from country to country...

We always work very closely with the local architect.

Sample coding of a polygamous network positioning

The best way of describing it right now is that it is a 'club’ which you pay membership

to. A basic fee common to all members is paid and then because of the different sizes of practices firms are weighted in terms of staff numbers we have a small and a large practice top-up:.. The bigger practices pay twice as much on the top-up as the small practices which is a way of making it fair. 
Table 2 Business Positioning and Network Positioning

\begin{tabular}{l|ll}
\hline$N=53$ & Promiscuous & Polygamous \\
\hline Strong ideas & 23 & 1 \\
Strong experience & 19 & 10 \\
\hline
\end{tabular}

Fisher's Exact (2-sided) 0.008; significant at the 1\% level. 
Table 3 Configurations of Practice in Professional Service Firms

\begin{tabular}{|c|c|c|}
\hline & Creators of architecture & Constructors of buildings \\
\hline $\begin{array}{l}\text { Business } \\
\text { positioning }\end{array}$ & $\begin{array}{l}\text { Strong ideas } \\
\text { The practice is driven by a culture of } \\
\text { architectural innovation in which peer } \\
\text { review by the architectural profession } \\
\text { is the paramount criterion of success. } \\
\text { Clients then bask in the reflected } \\
\text { glory of having commissioned a great } \\
\text { work of art }\end{array}$ & $\begin{array}{l}\text { Strong experience } \\
\text { The practice is driven by a strong } \\
\text { client orientation in which meeting } \\
\text { the needs of the client for particular } \\
\text { solutions to complex architectural } \\
\text { problems is paramount. }\end{array}$ \\
\hline $\begin{array}{l}\text { Network } \\
\text { positioning }\end{array}$ & $\begin{array}{l}\text { Promiscuous } \\
\text { Practices follow the work to wherever } \\
\text { the client is and continually ally with } \\
\text { local practices or set up temporary } \\
\text { offices. }\end{array}$ & $\begin{array}{l}\text { Polygamous } \\
\text { Practices create constellations on } \\
\text { either a managerial or collegial basis } \\
\text { in order to improve their ability to win } \\
\text { commissions from geographically } \\
\text { mobile clients. }\end{array}$ \\
\hline $\begin{array}{l}\text { New } \\
\text { market } \\
\text { entry }\end{array}$ & $\begin{array}{l}\text { Win an architectural competition } \\
\text { The principal entry route to new } \\
\text { national markets is to win an } \\
\text { architectural competition. Subsequent } \\
\text { commissions by invitation in that } \\
\text { market tend to be a function of the } \\
\text { reputation established as a result of } \\
\text { the successful competition. }\end{array}$ & $\begin{array}{l}\text { Follow a client } \\
\text { Entry to foreign markets is usually } \\
\text { due to following an established client } \\
\text { into that market. Clients happy with } \\
\text { the service rendered prefer to have the } \\
\text { familiar practice engage with the local } \\
\text { construction industry rather than } \\
\text { commission a new team. }\end{array}$ \\
\hline $\begin{array}{l}\text { Quality } \\
\text { assurance }\end{array}$ & $\begin{array}{l}\text { Centralised design control } \\
\text { The principal concern is that the } \\
\text { original architectural concept is } \\
\text { articulated and defended through the } \\
\text { project process. Network partners, } \\
\text { preferably small, that have no } \\
\text { pretension to being a strong ideas } \\
\text { practice are preferred if setting up a } \\
\text { temporary local office staffed from } \\
\text { the main office is not viable. }\end{array}$ & $\begin{array}{l}\text { Consistency of delivery } \\
\text { The principal concern is that the } \\
\text { realised building meets the } \\
\text { requirements of the client and the risk } \\
\text { of failure is reduced if trusted network } \\
\text { partners are used to interpret the } \\
\text { original concept to meet local } \\
\text { regulatory and social conditions. }\end{array}$ \\
\hline Reputation & $\begin{array}{l}\text { Distinctive building forms } \\
\text { The principal contributor to reputation } \\
\text { is that the realised building is } \\
\text { distinctively a building by the "star" } \\
\text { partner of the practice while } \\
\text { displaying innovative qualities } \\
\text { whether these are related to the } \\
\text { specific needs of the project or not. }\end{array}$ & $\begin{array}{l}\text { Specific building types } \\
\text { The principal contributor to reputation } \\
\text { is a track record in providing robust } \\
\text { solutions to client problems with } \\
\text { innovation limited to the specific } \\
\text { needs of the project. }\end{array}$ \\
\hline
\end{tabular}




\section{ECOLE d'ARCHITECTURE de GRENOBLE/ UNIVERSITY COLLEGE LONDON CASE STUDY INTERVIEWS: AIDE MEMOIRE (UK Version)}

SECTION A: THE PRACTICE
1) Size:
Number of partners
Number of employees/contract workers (now)
Turnover (average of last 5 years)
2) Foundation:
Who?
When?
Why (founding principles")

3) Profile:

Key events

Key projects

4) Strategic Position

Winch/Schneider matrix (explain dimensions).

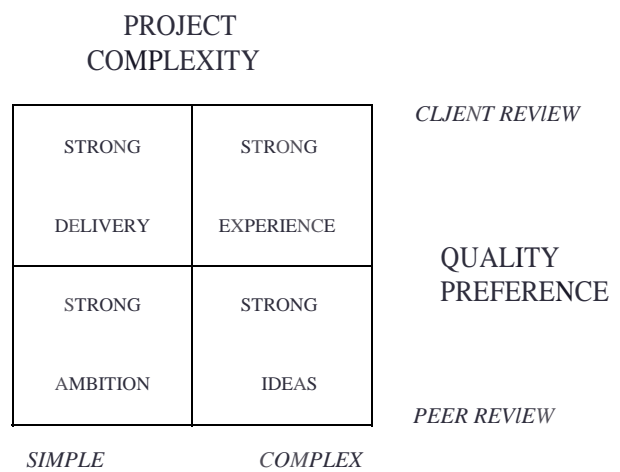

5) Strengths and Weaknesses

what would you say are your main strengths as a practice? what would you say are your main weaknesses?

6) Distinctive Competence

would you say that your practice has any distinctive competences that distinguish it from other architectural practices?

do you specialise in particular building types? 


\section{SECTION B FOREIGN EXPERIENCE}

1) Overall foreign experience

In which foreign markets have you worked (last 5 years)

Proportion of turnover from abroad (last five years)

How important is the French market to you (prop turnover)

How important is the German market to you (prop turnover)

How did you first enter the German/ French market

2) Current Situation

How many projects do you have in France/Germany

Have you worked for UK-based clients in F/D

Have you ever won a competition in F/D

Do you have a formal collaboration (joint venture) in F/D

Do you an informal collaboration (alliance) in F/D

Do you have an office in F/D

3) Please select a current (or recent) project which shows well your typical mode of working in France?

How did you get the commission?

Why do you think that you got it?

What skills do you offer that local practices cannot offer?

Are you collaborating with local practices?

IF YES why have you chosen to so collaborate?

IF NO how do you ensure adequate knowledge of liabilities, local building regulations etc?

What level of service are you offering (ref to RIBA Plan of Work/ Missions)?

How have you assured a supply of staff capable of working in F?

How would you summarise the experience on this project to date?

4) Please select a current (or recent) project which shows well your typical mode of working in Germany

How did you get the commission?

Why do you think that you got it?

What skills do you offer that local practices cannot offer?

Are you collaborating with local practices?

IF YES why have you chosen to so collaborate? 
IF NO how do you ensure adequate knowledge of liabilities, local building regulations etc?

What level of service are you offering (ref to RIBA Plan of Work)?

How have you assured a supply of staff capable of working in D?

How would you summarise the experience on this project to date?

\section{SECTION C: THE FUTURE}

1) How do you intend to build upon your current experience of working in France/Germany?

2) What do you see as the principal barriers to further work in other European countries?

3) How would you describe the differences between French/British/German architectural practice?

4) What are the prospects for the further development of the architectural profession at the European level? 


\section{References}

Abdelzaher, D.M. (2012). The Impact of Professional Service Firms’ Expansion: Challenges on Internationalization Processes and Performance. The Service Industries Journal, 32 (10), 1721-1738.

Aharoni, Y. (Ed.) (1993). Coalitions and Competition: The Globalization of Professional Business Services. London: Routledge.

Aharoni, Y. (1999). Internationalisation of Professional Services: Implications for Accounting Firms. In: D. Brock, M. Powell, \& Hinings, C. R. (eds.) (1999). Restructuring the Professional Organization: Accounting, Health Care and Law. (20-40). London: Routledge.

Apfelthaler, G., \& Vaiman, V. (2012). Challenges and Opportunities of Internationalization in Professional Service Industries. The Service Industries Journal, 32(10), 1589-1592.

Barney, J. (1991). Firm Resources and Sustained Competitive Advantage. Journal of Management, 17 (1), 99-120.

Barney, J. (2001) Is the Resource-based "View" a Useful Perspective for Strategic Management Research? Yes. Academy of Management Review, 26(1), 41-56.

Beaverstock, J.V., Taylor, P.J., \& Smith, R.G. (1999) The Long Arm of the Law: London's Law Firms in a Globalising World Economy. Environment and Planning A, 31, 18571876.

Boussebaa, M. (2009) Struggling to Organize across National Borders: The Case of Global Human Resource Management in Professional Service Firms. Human Relations, 62(6), 829-850.

Boussebaa, M., Morgan, G., \& Sturdy, A. (2009). Constructing Global Firms? National Transnational and Neocolonial Effects in International Management Consultancies. Organization Studies, 33(4), 465-486. 
Brass, D.J., Galaskiewicz, J., Greve, H.R., \& Tsai, W. (2004). Taking Stock of Networks and Organizations: A Multilevel Perspective. Academy of Management Journal, 47(6), 795817.

Brock, D.M. (2006) The Changing Professional Organization: A Review of Competing Archetypes. International Journal of Management Reviews, 8(3), 157-174.

Brock, D.M. (2012). Building Global Capabilities: A Study of Globalizing Professional Service Firms. The Service Industries Journal, 32 (10), 1593-1607.

Cooper, D. J., Rose, T., Greenwood, R., \& Hinings, B. (2000) History and Contingency in International Accounting Firms. In: Y. Aharoni, \& L. Nachum, (Eds.) (2000). Globalization of Service: Some Implications for Theory and Practice. (93-124). London: Routledge.

Daniels, P. W., Thrift, N. J., \& Leyshon, A. (1989). Internationalisation of Professional Producer Services: Accountancy Conglomerates. In: P. Enderwick (ed.) Multinational Service Firms. (79-106). London: Routledge.

Davidson, J., \& di Gregorio, S. (2011). Qualitative Research and Technology: In the Midst of a Revolution. In: N.K. Denzin \& Y.S. Lincoln. (Eds.) The Sage Handbook of Qualitative Research (pp. 627-643). Los Angeles, CA: Sage.

Eisenhardt, K.M. (1989). Building Theories from Case Study Research. Academy of Management Review, 14 (4), 532-550.

Eisenhardt, K.M., \& Graebner, M.E. (2007). Theory Building from Cases: Opportunities and Challenges Academy of Management Journal, 50(1), 25-32.

Granovetter, M. S. (1982). The strength of weak ties: a network theory revisited. In: P.V.

Marsden \& N. Lin (eds.) Social Structure and Network Analysis (pp. 105-130). Beverly Hills, CA: Sage. 
Helfat, C. E., Finkelstein, S., Mitchell, W., Peteraf, M.A., Singh, H., Teece, D.J., \& Winter, S.G. (2007). Dynamic Capabilities: Understanding Strategic Change in Organizations. Malden, MA: Blackwell.

Hitt, M.A., Bierman, L., Uhlenbruck, K., \& Shimizu, K., (2006). The Importance of Resources in the Internationalization of Professional Service Firms: The Good, the Bad and the Ugly. Academy of Management Journal, 49 (1), 1137-1157.

Jones, C., Hesterly, W.S., Fladmoe-Lindquist, K., \& Borgatti, S.P. (1998). Professional Service Constellations: How Stratetegies and Capabilities Influence Collaborative Stability and Change. Organization Science, 9(3), 396-410.

Koka, B.R., \& Prescott, J.E. (2008). Designing Alliance Networks: The Influence of Network Position, Environmental Change, and Strategy on Firm Performance. Strategic Management Journal, 29, 639-661.

Koza, M.P., \& Lewin, A.Y. (1999). The Coevolution of Network Alliances: A Longitudinal analysis of an International Professional Service Network. Organization Science, 10(5), 638-653.

Krull, E., Smith, P., \& Ge, G.L. (2012) The Internationalization of Engineering Consulting from a Strategy Tripod Perspective. The Service Industries Journal, 32(7), 1097-1119.

Larson, M. S. (1993). Behind the Postmodern Façade: Architectural Change in late Twentieth-century America. Berkeley, CA: University of California Press.

Larsson, R. (1993). Case Survey Methodology: Quantitative Analysis of Patterns across Case Studies Academy of Management Journal, 36(6), 1515-1546.

Maister, D. (1982). Balancing the Professional Service Firm. Sloan Management Review, Fall, 15-29.

McNeill, D. (2009) The Global Architect: Firms, Fame and Urban Form. New York, NY: Routledge. 
Malhotra, N., \& Morris, T. (2009). Heterogeneity in Professional Service Firms. Journal of Management Studies, 46(6), 895-922.

Miller, D. (1996). Configurations Revisited. Strategic Management Journal, 17, 505-512.

Morgan, G., \& Quack, S. (2005). Institutional Legacies and Firm Dynamics: The Growth and Internationalization of UK and German Law Firms. Organization Studies, 26(12), 17651785.

Nachum, L. (1997) Home Countries’ Effects of the Competitive Position of Advertising Agencies: Contrasting Success and Failure. In Y. Aharoni, (Ed.) (1997). Changing Roles of State Intervention in Services in and Era of Open International Markets. (180196). Albany, NY: SUNY Press.

Peng, M.W., Sun S.L., Pinkham, B., \& Chen, H. (2009). The Institution-Based View as a Third Leg for a Strategy Tripod. Academy of Management Perspectives, 23, 63-81.

Pla-Barber, J., \& Ghauri, P. N. (2012) Internationalization of Service Industry Firms: Understanding Distinctive Characteristics The Service Industries Journal, 32 (7), 10071010.

Porter, M. (1980). Competitive Strategy. New York, NY: Free Press.

Porter, M. (1985). Competitive Advantage. New York, NY: Free Press.

Porter, M., \& Siggelkow, N. (2008). Contextuality within Activity Systems and Sustainability of Competitive Advantage. Academy of Management Perspectives, May, 34-56

Prost, R. (1997). Pratiquer l'Architecture à l'Echelle Européenne: Un Défi? Paris : CSTB.

Rimmer, P.J. (1988). The Internationalization of Engineering Consultancies: Problems of Breaking into the Club. Environment and Planning A, 20, 761-788.

Rose, T., \& Hinings, C. R. (1999). Global Client's Demands Driving Change in Global Business Advisory Firms. In: D. Brock, M. Powell, \& C. R. Hinings, (Eds.) (1999). 
Restructuring the Professional Organization: Accounting, Health Care and Law. (4167). London: Routledge.

Scheuer, M. (2003). The International Competitiveness of German Consulting Engineering: Results of an International Benchmarking Study. The Service Industries Journal, 23 (1), 95-118.

Scott-Kennel, J., \& von Batenburg, Z. (2012). The Role of Knowledge and Learning in the Internationalisation of Professional Service Firms. The Service Industries Journal, 32(10), 1667-1690.

Segal-Horn, S., \& Dean, A. (2011) The Rise of Super-elite Law Firms: Towards Global Strategies. The Service Industries Journal, 31 (2), 195-213.

Siggelkow, N. (2011). Firms as Systems of Interdependent Choices. Journal of Management Studies. 48(5), 1126-1140.

Spar, D. L. (1997). Lawyers Abroad: The Internationalization of Legal Practice. California Management Review, 39(3), 8-28.

Von Nordenflycht, A. (2010). What is a Professional Service Firm? Toward a Theory and Taxonomy of Knowledge-Intensive Firms. Academy of Management Review, 35(1), 155-174.

Wernerfelt B. (1984). A Resource-based View of the Firm. Strategic Management Journal, 5, 171-180.

Winch, G. M. (2008). Internationalisation Strategies in Business-to-Business Services: The Case of Architectural Practice. The Service Industries Journal, 28(1), 1-13.

Winch, G. M., Grèzes, D., \& Carr, B. (2002). Exporting Architectural Services: The English and French Experiences. Journal of Architectural and Planning Research, 19(2), 165175. 
Winch, G. M., \& Schneider, E. (1993). Managing the Knowledge-Based Organization: The Case of Architectural Practice. Journal of Management Studies, 30 (3), 923-937.

Yin, R.K. (2009). Case Study Research: Design and Methods. (4 ${ }^{\text {th }}$ ed.) Los Angeles, CA: Sage. 